\title{
PERANAN PERBANKAN DALAM PENCEGAHAN DAN PEMBERANTASAN TIDAK PIDANA PENCUCIAN UANG MELALUI PENERAPAN UNDANG-UNDANG NOMOR 8 TAHUN 2010 TENTANG TINDAK PIDANA PENCUCIAN UANG DAN UNDANG-UNDANG NOMOR 3 TAHUN 2004 TENTANG PERBANKAN
}

Herlina Basri

Fakultas Hukum Universitas Pamulang

Email : basri_herlina@yahoo.com

Received: - /Revised: - /Accepted: Ags 2018

\begin{abstract}
Secara umum, money loundering merupakan metode untuk menyembunyikan, memindahkan, dan menggunakan hasil dari suatu tindak pidana, kegiatan organisasi tindak pidana, tindak pidana ekonomi, korupsi, perdagangan narkotika dan kegiatankegiatan lainnya yang merupakan aktivitas tindak pidana. Pada dasarnya kegiatan tersebut terdiri dari tiga tahapan yang masingmasing berdiri sendiri tetapi seringkali dilakukan bersama-sama, Tahapan tersebut adalah Placement, Layering, Integration. Peranan Perbankan dalam Tindak Pidana Pencucian Uang disini Bank adalah lembaga kepercayaan masyarakat yang memiliki kedudukan dan peranan penting dalam sistem perekonomian suatu negara, sehingga bank sering disebut sebagai jantung dari sistem keuangan. Keberadaan aset bank dalam bentuk kepercayaan masyarakat perlu selalu dijaga mengingat kepercayaan masyarakat sangat dibutuhkan bank untuk meningkatkan efisiensi penggunaan dan fungsi bank serta mencegah terjadinya bank runs and panics. Ada 3 tujuan kriminalisasi pencucian uang. Pertama, pencucian uang merupakan masalah yang serius bagi dunia international, maka harus dilakukan kriminalisasi. Kedua, aturan anti pencucian uang dipandang sebagai cara yang paling efektif untuk mencari pemimpin organisasi kejahatan ekonomi (leaders of organize criminal enterprise). Ketiga, bahwa pelaku pencucian uang lebih mudah di tangkap dari pada menangkap pelaku kejahatan utamanya (Predicate Offence).
\end{abstract}

Kata Kunci : Peran Perbankan, Pencucian Uang, Kejahatan Khusus. 


\begin{abstract}
In general, money loundering is a method to hide, move, and use the proceeds of a criminal offense, the activities of criminal organization, economic crime, corruption, narcotics trade and other activities constituting criminal activity. Basically the activity consists of three stages which each stand alone but often done together, The Stages are Placement, Layering, Integration. The Role of Banking in Money Laundering Criminology here Bank is a public trust institution that has a position and an important role in the economic system of a country, so that banks are often referred to as the heart of the financial system. The existence of bank assets in the form of public trust should always be maintained considering the public trust is needed by the bank to improve the efficiency of the use and function of banks and prevent the occurrence of bank runs and panics. There are three purposes for criminalizing money laundering. First, money laundering is a serious problem for the international community, it must be criminalized. Second, anti money laundering rule is seen as the most effective way to find leaders of organize criminal enterprise. Third, that money launderers are easier to catch than to catch the main perpetrator (Predicate Offence).
\end{abstract}

Keywords: Role of Banking, Money Laundering, Special Crimes.

\title{
PENDAHULUAN
}

Secara umum, money loundering merupakan metode untuk menyembunyikan, memindahkan, dan menggunakan hasil dari suatu tindak pidana, kegiatan organisasi tindak pidana, tindak pidana ekonomi, korupsi, perdagangan narkotika dan kegiatankegiatan lainnya yang merupakan aktivitas tindak pidana. ${ }^{1}$ Kegiatan pencucian uang melibatkan pencucian uang yang sangat kompleks. Pada dasarnya kegiatan tersebut terdiri dari tiga langkah yang masing-masing berdiri sendiri tetapi seringkali

\footnotetext{
${ }^{1}$ Yunus Husein. Makalah: "Upaya Pemberantasan Pencucian Uang”, hal 2
} 
dilakukan bersama-sama yaitu placement, layering, dan integration. $^{2}$

Maraknya kasus money laundering di Indonesia ini cukup menimbulkan dampak yang signifikan bagi lalu lintas neraca pembayaran. Kegiatan money laundering dianggap sebagai kejahatan terorganisir, yang selalu dilakukan oleh orang yang menguasai atau mempunyai pengetahuan khusus di dunia penyedia jasa keuangan. Bahkan mereka harus menguasai ilmu pengetahuan di bidang komputer.

Salah satu contoh dari kasus money laundering ialah kasus Bank Global. Pembobolan bank tersebut bukan dilakukan melalui suatu teknik yang canggih, melainkan karena adanya niat buruk dari pengelola bank yang memanfaatkan kelengahan pengawasan BI maupun Bapepam. Maka dari itu pemerintah menutup Bank Global. Pada waktu dibekukan kegiatan usahanya, Bank Global sudah nyaris kolaps. Angka Capital Adequacy Ratio (CAR) atau rasio kecukupan modalnya sudah berada pada titik minus $39 \%$. Dengan adanya indikasi berbagai pelanggaran ditambah dengan ketertutupan dari pihak manajemen, maka BI kemudian bertindak lebih tegas, yakni membekukan kegiatan usaha dengan tujuan demi menyelamatkan asset, mencegah kerugian lebih besar lagi, serta yang utama ialah mengamankan dana nasabah.

Menurut Pasal 1 ayat (1) Undang-Undang no 25 th 2003, Pencucian uang adalah perbuatan menempatkan, mentransfer, membayar, menghibahkan, dan membawa keluar negeri atas harta yang patut diduga merupakan hasil tindak pidana dengan maksud untuk menyembunyikan, atau menyamarkan asal usul harta kekayaan sehingga seolah-olah menjadi harta kekayaan yang sah.

${ }^{2} \mathrm{Ibid}, \mathrm{hlm} 2$ 
Adapun menurut peraturan tindak pidana ekonomi dapat ditemukan pada pada Undang-Undang darurat no. 7 th 1955 dalam arti sempitnya. Sedangkan dalam arti luasnya, tindak pidana dibidang ekonomi meliputi sbb;

a. Undang-Undang no 10 th 1998 tentang perbankan.

b. Undang-Undang no 7 th 1987 tentang hak cipta.

c. Undang-Undang no 20 th 2001 tentang tindak pidana korupsi.

d. Undang-Undang no 25 th 2003 tentang tindak pidana pencucian uang

Untuk menjadikan agar undang-undang ini menjadi efektif maka dibentuklah Pusat Pelaporan Analisis Transaksi Keuangan (PPATK). Menurut Pasal 26 Undang-Undang no 25 tahun 2003 Adapun tugas PPATK antara lain;

a. Mendeteksi, mengumpulkan, menyimpan, menganalisi informasi yang diparoleh PPATK bedasarkan undang-undang yang berlaku. -Pelapor bisa orang-perorang, kelompok dan instansi.

b. Merekomendasikan pada penegak hukum.

-Menurut pasal 26 g Undang-Undang nomor 25 tahun 2003 PPATK wajib melaporkan hasil analisis pada kepolisian dan kejaksaan.

-Menurut pasal 26 h Undang-Undang nomor 25 tahun 2003 PPATK wajib memberikan laporan pada Presiden setiap, DPR, dan lembaga yang berwenang melakukan pengawasan terhadap penyedia jasa keuangan setiap 6 bulan sekali.

Contoh kasus jika seseorang melakukan seseorang melakukan penjualan narkoba senilai $\mathrm{Rp}$ 400.000.000,00 atau dibawah $\mathrm{Rp}$ 500.000.000,00 lalu kemudian memasukannya ke Bank dalam deposito pribadinya, maka pihak Bank tidak akan menaruh kecurigaan terhadap orang tesebut, sebab menurut syarat untuk dicurigai uang tersebut dimungkinkan dari kejahatan harus yang 
nilai $\mathrm{Rp} 500.000 .000,00$ baru dapat dicurigai sebagai hasil dari suatu kejahatan sebagaimana yang disebutkan diatas.

Padahal menurut Pasal 1 ayat (7) kolom a Undang-Undang no 25 tahun 2003, yang dimaksud dengan transaksi mencurigakan adalah transaksi yang menyimpang dari profil dan karakteristik. Logikanya jika seseorang menabung di bank senilai Rp 450.000.000,00 dan ia tidak bisa memberi keterangan dengan jelas darimana uang tersebut ia dapat maka saat ditanyai bahwa ia adalah seorang pengangguran atau pada profesinya tidak memadai untuk sampai memiliki uang sebesar itu maka patut dicurigai bahwa ia mungkin telah mendapatkan uang tersebut dari proses yang tidak halal atau tidak sah dari kejahatan yang tertera pada Pasal 2 Undang-Undang no 25 tahun 2003. Ini merupakan penyimpangan antara Pasal 2 Undang-Undang no 25 tahun 2003 dengan Pasal 13 ayat 1 Undang-Undang no 25 tahun 2003 yang menyebabkan merubah pengertian dan definisi Money laundering itu sendiri dan dapat berkibat aturan tersebut jadi tidak tegas dan lemah.

Tujuan dibuatnya undang-undang tindak pidana pencucian uang adalah untuk dapat mendeteksi dan menangkap pelaku kejahatan pada saat orang tersebut menyimpan uangnya di Bank untuk menutupi jejak kejahatannya. Pada awalnya istilah money laundry dikenal pada tahun 1930 di Amerika Serikat oleh seorang Mafia yang bernama Alcophone. Dia adalah seorang yang pertama kali melakukan pencucian uang. Pada saat itu Alcophone membeli banyak perusahaan pencucian pakaian (laundery) untuk mencuci uangnya. Kemudian pihak kepolisian Amerika Serikat menangkap Alcophone bukan dengan tuduhan penjualan narkotika, pembunuhan, perjudian, atau kejahatan lainnya, tetapi karena 
Alcophone tidak melaporkan bahwa dia memiliki uang sebanyak itu pada pihak kepolisian.

Secara etimologis money laundering terdiri dari kata money yang berarti uang dan laundering yang berarti pencucian. Jadi money laundering adalah pencucian uang.

Sesuai dengan Pasal 2 angka 1 Undang-Undang Nomor 25 Tahun 2003, tindak pidana yang memicu terjadinya pencucian uang meliputi korupsi, penyuapan, penyelundupan barang, penyelundupan tenaga kerja, penyelundupan imigran, di bidang perbankan, dibidang pasar modal, di bidang asuransi, narkotika, psikotropika, perdagangan manusia, perdagangan senjata gelap, penculikan, terorisme, pencurian, penggelapan, penipuan, pemalsuan uang, perjudian, prostitusi, dibidang perpajakan, di bidang kehutanan, di bidang lingkungan hidup, dibidang kelautan atau tindak pidana lainnya yang diancam dengan penjara 4 (empat) tahun atau lebih, yang dilakukan di wilayah Negara Republik Indonesia atau di luar wilayah Negara Republik Indonesia dan tindak pidana tersebut juga merupakan tindak pidana menurut hukum Indonesia. ${ }^{3}$

Tindak pidana pencucian uang merupakan organized crime sehingga penangulangannya merupakan tanggungjawab negara per negara yang diwujudkan dalam kerjasama regional atau internasional melalui forum bilateral dan multilateral.

\section{PERMASALAHAN}

Dari uraian latar belakang masalah di atas, penulis tertarik mengangkat masalah yang diteliti dalam tesis ini yaitu:

\footnotetext{
${ }^{3}$ Undang-undang Nomor 25 Tahun 2003
} 
1. Peranan Perbankan dalam pencegahan dan pemberantasan tindak pidana pencucian uang melalui penerapan UndangUndang No. 8 Th 2010 tentang tindak pidana pencucian uang dan Undang-Undang No. 3 Th 2004 tentang Perbankan.

2. Penerapan Hukuman terhadap Tindak Pidana pencucian uang dalam transaksi perbankan ditinjau dari UndangUndang Nomor 8 Tahun 2010 tentang Tindak Pidana Pencucian Uang dan Undang-Undang Nomor 3 Tahun 2004 Tentang Perbankan.

\section{TUJUAN DAN MANFAAT PENELITIAN}

1. Tujuan Penelitian :

a. Untuk memahami peranan perbankan dalam pencegahan Tindak Pidana Pencucian Uang

b. Untuk mengetahui penerapan hukuman terhadap pelaku Tindak Pidana Pencucian Uang dalam transaksi perbankan melalui Undang-undang Nomor 8 Tahun 2010 Tentang Tindak Pidana Pencucian Uang dan Undang-Undang Nomor. 3 Tahun 2004 Tentang Perbankan

2. Manfaat Penelitian:

a. Hasil penelitian ini diharapkan dapat bermanfaat dan dijadikan sebagai bahan refrensi sekaligus sebagai bahan wacana bagi semua pihak yang berkepentingan dalam rangka pengembangan ilmu pengetahuan secara umum dan pengembangan hukum kepidanaan secara khusus dalam bidang pencucian uang. 
b. khasana ilmu pengetahuan bagi para penegak hukum dalam menangani masalah mengenai pencucian uang terlebih dalam pencucian uang dalam transaksi perbankan

\section{METODE PENELITIAN}

Metode pengumpulan data yang kami gunakan untuk menunjang dan memperkaya tesis ini adalah dengan :

1. Metode Pendekatan

Bambang Sunggono menyatakan bahwa dalam penulisan sebuah karya ilmiah ada terdapat 2 (dua) jenis metode penelitian yaitu :

a. Penelitian Yuridis Normatif disebut juga penelitian hukum doktrinal karena penelitian ini dilakukan atau ditujukan hanya kepada peraturan-peraturan yang tertulis dan bahan hukum yang lain. Penelitian hukum ini juga disebut sebagai penelitian kepustakaan ataupun studi dokumen disebabkan penelitian ini lebih banyak dilakukan terhadap data yang bersifat sekunder yang ada diperpustakaan. Penelitian kepustakaan demikian dapat pula dikatakan sebagai lawan dari penelitian empiris (penelitian lapangan). 4

b. Penelitian yuridis empiris disebut juga dengan penelitian hukum non doctrinal karena penelitian ini berupa studistudi empiris untuk menemukan teori-teori mengenai proses terjadinya dan mengenai proses bekerjanya hokum didalam masyarakat. Atau yang disebut juga sebagai Socio Legal Research.

${ }^{4}$ Bambang Sunggono, Metode Penelitian Hukum, Jakarta : PT. Raja Grafindo Persada, 2007, hlm. 81 
Adapun metode penelitian yang dipergunakan dalam penulisan tesis ini adalah metode penelitian hokum normatif atau penelitian yuridis normatif yaitu dengan pengumpulan data secara studipustaka (library research)

2. Sumber data

Penelitian hukum yang bersifat normatif selalu menitikberatkan pada data sekunder. Data sekunder pada penelitian dapat dibedakan menjadi :

a. Bahan hukum primer, yaitu norma atau kaedah dasar, bahan hukum yang mengikat seperti Kitab Undang-undang Hukum

Pidana maupun peraturan-peraturan lain yang berkaitan dengan kebijakan hukum pidana dalam peraturan perundangundangan di Indonesia tentang tindak pidana pencucian uang dalam hal ini termasuk Undang-Undang Nomor 8 Tahun 2010 tentang Pencegahan Pemberantasan Tindak Pidana Pencucian Uang.

b. Bahan hukum sekunder, yang memberikan penjelasan mengenai bahan hukum primer, seperti Undang-Undang Nomor 15 Tahun 2002 tentang Tindak Pidana Pencucian Uang, Undang-Undang Nomor 25 Tahun 2003 tentang perubahan atas Undang-Undang Nomor 15 Tahun 2003 tentang Tindak Pidana Pencucian Uang, dan lain-lain.

c. Bahan hukum tersier, yakni bahan yang memberikan petunjuk maupun penjelasan terhadap bahan hukum primer dan sekunder, seperti Kamus Besar Bahasa Indonesia, kamus Inggris-Indonesia, Kamus hukum, ensiklopedia dan lain-lain.

3. Metode Pengumpulan data

Dalam penulisan tesis ini, penulis menggunakan teknik pengumpulan data yaitu melalui Penelitian Kepustakaan atau 
Library Research yaitu penelitian dengan mengumpulkan data dan meneliti melalui sumber bacaan yang berhubungan dengan judul tesis ini, yang bersifat teoritis ilmiah yang dapat dipergunakan sebagai dasar dalam penelitain dan menganalisa masalah-masalah yang dihadapi. Penelitian yang dilakukan dengan membaca serta menganalisa peraturan Perundangundangan maupun dokumentasi lainnya seperti karya ilmiah para sarjana, majalah, surat kabar, internet, maupun sumber teoritis lainya yang berkaitan dengan materi tesis yang penulis ajukan.

\section{PEMBAHASAN}

Bagaimana Peranan Perbankan dalam Pencegahan dan Pemberantasan Tindak Pidana Pencucian Uang dalam Penerapan Undang-Undang Nomor 8 Th 2010 tentang Tindak Pidana Pencucian Uang di Indonesia.

Tindak Pidana Pencucian Uang/Money Laundering (selanjutnya dikatakan Tindak Pidana Pencucian Uang) merupakan kejahatan yang baru di Indonesia. Dikatakan demikian karena Indonesia baru mengkriminalisasikan dan menjadikannya Undang-Undang pertama kali pada tahun 2002.

Tindak Pidana Pencucian Uang dimaksudkan untuk memberatas tindak pidana dengan cara follow the money. Karena dengan cara itu dapat memutus aliran darah dalam suatu organisasi kriminal (organization crime). Para ahli juga menyebutkan bahwa Tindak Pidana Pencucian Uang memberantas tindak pidana pada "hilir"nya.

Paling sedikit ada 3 tujuan kriminalisasi pencucian uang. Pertama, pencucian uang merupakan masalah yang serius bagi dunia international, maka harus dilakukan kriminalisasi. Kedua, 
aturan anti pencucian uang dipandang sebagai cara yang paling efektif untuk mencari pemimpin organisasi kejahatan ekonomi (leaders of organize criminal enterprise). Ketiga, bahwa pelaku pencucian uang lebih mudah di tangkap dari pada menangkap pelaku kejahatan utamanya (Predicate Offence). 5

Berkaitan dengan alasan atau tujuan yang pertama bahwa pencucian uang menjadi permasalahan internasional yang paling tidak terdapat pada dua konferensi internasional. Pertama, konfrense of money trail: International money laundering trends prevention/ control polish, yang diselenggarakan di Coremayeur, Italia pada juni 1994. Pentingnya konferensi ini bagi tujuan kriminalisasi nampak dalam pernyataan 6 :

"...This combination of difrent experience coming from governmental and reaserch field has ensure that this convrense in Coremayeour should become a milisten in the debate on antimoney loundering policies."

Konferensi yang kedua adalah United Nation Congres on The Prevention of Crime and Treatment of Offenders, $1995 \mathrm{di}$ Cairo yang menyatakan bahwa ada tujuh belas jenis kejahatan yang dikategorikan sebagai kejahatan serius (serious criemes) dan diantara itu pencucian uang menempati urutan pertama. ${ }^{7}$ Masih berkaitan dengan tujuan yang pertama yaitu bahwa praktik pencucian uang pada umumnya menggunakan sarana lembaga keuangan maka kejahatan ini sanggat

${ }^{5}$ Sultzer, Money Laundering, Hal 145-146.

6 W.C.Gilmore, Dirty Money-the evaluation of money laundering counter measures, Strassbourg:Counsile of Europe Press, 1995, hal 2

${ }^{7}$ David A. Chaikin, "Money Laundering”, hal. 47138 
membahayakan dan dapat merusak lembaga keuangan baik lembaga perbankan ataupun non perbankan. ${ }^{8}$

Selain itu lembaga-lembaga ini dimanfaatkan para pelaku pencucian uang, biasanya juga terjadi antar negara dan menggunakan teknik yang canggih. ${ }^{9}$ Oleh karenanya salah satu tujuan kriminalisasi pencucian uang termasuk untuk melindungi keuangan internasional. Tujuan seperti ini juga nampak dalam European Council / Council Directive 91/308, tahun 1991 yang pada dasarnya untuk mencegah di gunakannya fasilitas perbankan dalam praktik pencucian uang. ${ }^{10}$

Tujuan yang kedua yaitu, bahwa kriminalisasi merupakan cara yang paling efektif untuk menangkap pelaku atau pemimpinb kejahatan ekonomi terorganisasi. Ada dua bentuk kejahatan yang berbahaya yaitu kejahatan ekonomi dan kejahatan terorganisasi. ${ }^{11}$ Penekanan pada kegiatan ekonomi sah yang di lakukan oleh kelompok kejahatan terorganisasi, misalnya seperti yang dilakukan di Australia melalui poker macine and club industri, gamingmachine conceerns, unions, and waterfrond. 12 Sedangkan di eropa bisnis kelompok kejahatan terorganisasi pada umumnya dilakukan dalam kegiatan pasar uang. ${ }^{13}$

${ }^{8}$ Gerhard O.W. Muller, former director of the UN Congres for Prevention of Crime and Treatment of Offenders, Statement at Workshop on "Global Struggle aggaints Organized Crime" at the $27^{\text {th }}$ International Menejement Symposium, St. Gallen, Switzerland, (May 2628, 1997)

${ }^{9}$ Baldwin, “Wire Transfer.” hal 413.

${ }^{10}$ Barbot, "Money Laundering”, hal. 164-165.

${ }^{11}$ Smith, "Service Industry", hal. 105.

${ }^{12}$ Harmon, "Money Laundering Law", hal. 22.

${ }^{13}$ R. Bosworth Davies, "Euro-Fiannce: The Influence of Organized Crime”, makalah dalam The Eighth InJternational Symposiom on Economic Crime, Cambridge, England, July 29-Aug 30, 1991, hal 3JJ 
Akibat buruk dari kegiatan tersebut tidak saja menyangkut kegiatan ekonomi dan lembaga keuangan itu sendiri tetapi juga menimbulkan bisnis yang tidak fair. Para pelaku pencucian uang ini pada umumnya tidak akan memperhatikan kewajiban pembayaran pajak atau kewajiban-kewajiban lain yang ditentukan. Mereka hanya menikmati akses yang ada untuk mendapatkan keuntungan atau mengubah uang mereka menjadi sah. ${ }^{14}$

Indonesia salah satu dari 16 negara yang dimasukkan dalam daftar hitam (black list) negara yang tidak kooperatif dalam pemberantasan pencucian uang di dunia. Masuknya Indonesia dalam daftar hitam karena Indonesia terlambat mengkriminalisasikan pencucian uang. Faktor yang membuat Indonesia terlambat membuat Undang-Undang Tindak Pidana Pencucian Uang menurut Yenti Garnasih ialah: "Karena Indonesia turut serta dalam menikmati hasil pencucian uang tersebut". Indonesia masih butuh banyak uang untuk mendongkrang perekonomian sehingga tak perlu melihat sumber dana tersebut.

\section{Perkembangan Undang-Undang Tindak Pidana Pencucian Uang di Indonesia.}

Berikut perjalanan perkembangan Undang-Undang Tindak Pidana Pencucian Uang di Indonesia: Penerapan peraturan yang memberikan perlindungan hukum pada terdakwa dalam kaitanya dengan keterangan saksi yang tidak dapat dipercaya secara tegas dapat dilihat dalam Undang-undang Republik Indonesia Nomor 8 tahun 1981 tentang KUHAP yaitu dalam Pasal 185 ayat 6 KUHAP. Ketentuan-ketentuan tersebut adalah untuk

\footnotetext{
${ }^{14}$ David A. Chaikin, "Money Laundering”, hal. 47140.
} 
mengingatkan hakim agar memperhatikan keterangan saksi secara bebas, jujur, dan objektif.

\section{Undang-Undang Nomor 15 Tahun 2002}

Sebagai negara yang baru meng-Undang-Undangkan Tindak Pidana Pencucian Uang tentu masih banyak celah dalam aturan ini. Walaupun telah diberikan arahan oleh FATF dalam membentuk Undang-Undang Tindak Pidana Pencucian Uang seperti 40+9 Recomendasi FATF tetapi Indonesia masih belum dapat menerapkan keseluruhan rekomendasi tersebut. Itu yang membuat Indonesia belum keluar dalam daftar hitam (black list) NCCTs (Non-Cooperative Countries and Territories).

Berikut hasil sidang rapat pleno FATF 18-21 Juni 2002 dan 24 Oktober 2002 hasil sidang rapat pleno FATF 9-11 Oktober 2002 FATF menegaskan terdapat 10 (sepuluh) hal yang harus diperhatikan oleh Indonesia untuk dapat membangun rezim anti pencucian yang efektif dan memenuhi international best practice, yaitu: 1. Belum adanya kerangka pengaturan yang komprehensif dalam kaitannya dengan standar anti pencucian uang untuk lembaga keuangan non-bank, seperti asuransi dan stockbrokers. 2 . Belum adanya ketentuan tentang fit and proper test untuk lembaga keuangan non-bank. 3. Belum adanya ketentuan tentang know your customer untuk lembaga keuangan nonbank. 4. Perlunya memperluas pengertian transaksi keuangan yang mencurigakan dalam Undang-Undang Tindak Pidana Pencucian Uang, sehingga termasuk kewajiban melaporkan transaksi yang diduga menggunakan dana hasil dari kejahatan. 5. Belum adanya ketentuan larangan pemberian informasi ("tipping off") dalam Undang-Undang Tindak Pidana Pencucian Uang. 6. 
Perlunya mempersingkat jangka waktu pelaporan transaksi keuangan mencurigakan dari PJK kepada PPATK, karena 14 hari dinilai terlalu lama. 7. Perlunya meniadakan batasan (threshold) hasil kejahatan (proceed of crime) yang dalam Undang-Undang Tindak Pidana Pencucian Uang ditetapkan sebesar Rp 500 juta. 8. Adanya potensi untuk tidak dapat membekukan dan menyita hasil kejahatan yang besarnya dibawah batasan Rp 500 juta. 9 . Belum adanya ketentuan yang mengatur bantuan hukum timbal balik (mutual legal assistance), dan 10. Belum beroperasinya PPATK sebagai FIU.

\section{Undang-Undang Nomor 25 Tahun 2003}

Sebagai tindak lanjut (follow up) dari hasil sidang pleno FATF bahwa Indonesia masih masuk dalam daftar hitam (black list) NCCTs (Non- Cooperative Countries and Territories) dan perlu banyak perbaikan dalam UU no 15 tahun 2002 maka Indonesia memperbaharui dengan di Undang- Undangkan nya UndangUndang Nomor 25 Tahun 2003.

Upaya perbaikan dan penyempurnaan undang-undang tersebut pun akhirnya dapat diselesaikan oleh pemerintah RI dengan diundangkannya Undang-Undang No.25 Tahun 2003 tentang Perubahan atas Undang-undang No. 15 Tahun 2003 tentang Tindak Pidana Pencucian Uang pada tanggal 13 Oktober 2003 (Undang-Undang Tindak Pidana Pencucian Uang). Beberapa perubahan yang mendasar antara lain adalah: 1. penghapusan definisi hasil tindak pidana yang dikaitkan dengan jumlah uang sebesar Rp 500 juta; 2. perluasan tindak pidana asal dari 15 jenis menjadi 25 jenis, termasuk di dalamnya tindak pidana lainnya sepanjang ancaman pidananya 4 tahun atau lebih; 3. perluasan 
definisi transaksi keuangan mencurigakan, sehingga termasuk transaksi yang diduga menggunakan dana hasil dari kejahatan; 4 . penambahan ketentuan anti- tipping off; 5 . pengurangan masa pelaporan transaksi keuangan mencurigakan dari 14 (empat belas) hari menjadi 3 (tiga) hari; 6. penambahan ketentuan mengenai bantuan hukum timbal balik (mutual legal assistance).

Undang-Undang Nomor 8 tahun 2010 Tentang Pencegahan dan Pemberantasan Tindak Pidana Pencucian Uang.

Setelah tanggal 11 Februari 2005 Indonesia secarah sah telah keluar dari daftar hitam (black list) NCCTs dan berkomitmen untuk terus melakukan pencegahan dan pemberantasan Tindak Pidana Pencucian Uang di Indonesia. Tetapi tetap saja masih ada beberapa kekurangan yang nampak dalam Undang-Undang Tindak Pidana Pencucian Uang terbaru ini. Menurut Yenti Garnasih masih ada kekurangan pada pihak pelapor karena hanya sebagaian kecil yang diberi kewajiban dalam melakukan pelaporan sedangkan cakupan pencucian uang sangat besar. Beliau mengatakan bahwa perlu ditambahkan sebagai pihak pelapor seperti profesi akuntan publik, notaris, pengacara dll. Beliau juga kurang setuju pada pasal 69 mengenai penuntutan in absentia bahwa maksud dari Tindak Pidana Pencucian Uang itu sebagai wadah untuk memberantas tindak pidana asal (predicate crime) bukan hanya sekedar memberantas Tindak Pidana Pencucian Uang. Terdapat celah juga pada pasal 71-74 mengenai penetapan penuntut pada kasus Tindak Pidana Pencucian Uang karena dapat menimbulkaan multi tafsir terhadap siapa yang akan menjadi penuntut terhadap kasus Tindak Pidana Pencucian Uang sesuai dengan pidana asalnya. 
Tindak Pidana Pencucian Uang (Money Laundering) dalam Transaksi Perbankan.

Perbankan merupakan wadah yang cukup digemari para pelaku pencucian uang di tanah air. Hal tersebut dapat dilihat dari statistik PPATK bahwa dilihat dari sisi jumlah pelapor, Selama Januari 2015 s.d. April 2015 tercatat sebanyak 211 Penyedia Jasa Keuangan telah menyampaikan laporan transaksi keuangan mencurigakan (selajutnya dikatakan LTKM) kepada PPATK. Sebagian besar Laporan Transaksi Keuangan Mencurigakan atau sebanyak 56,9 persen disampaikan oleh Penyedia Jasa Keuangan Non Bank, sedangkan 43,1 persen selebihnya disampaikan oleh Penyedia Jasa Keuangan Bank, Mayoritas Transaksi Keuangan Mencurigakan selama priode ini terjadi di Jakarta (45,0 persen), dan Jawa Timur (11,5 persen).

Penerapan Undang-Undang No. 8 Tahun 2010 Tentang Tindak Pidana Pencucian Uang

\section{Identitas Terdakwa}

Nama: H. Tubagus Chaeri Wardana Chasan

Tempat lahir : Serang-Banten

Umur/tanggal lahir : : 47 tahun/ 21 mei 1969

Jenis kelamin : Laki-laki

Kebangsaan: Indonesia

Tempat tinggal : Jl Denpasar IV No. 35 Jakarta Selatan

Jl Denpasar II No. 43 Jakarta Selatan

Agama : Islam

Pekerjaan : Pemilik PT Bali Pasific Pragama

Pemilik PT Adcha Mandiri

Pemilik PT Waliman Nugraha Jaya

Pemilik PT Marbago 
Pemilik PT Buana Wardana Utama

Pemilik CV Bina Sadaya

2. Posisi Kasus

Bahwa Terdakwa suami Wali Kota Tangerang Selatan (Tangsel) Airin Rachmi Diany, Tb Chaeri Wardhana alias Wawan. Kali ini Wawan ditetapkan tersangka dalam kasus dugaan korupsi pengadaan alat kesehatan (Alkes) kedokteran umum di Puskesmas Tangsel Tahun 2012. Juru Bicara KPK Johan Budi SP menyatakan, peningkatan status tersangka kepada Wawan dilakukan setelah melalui penyelidikan dan gelar perkara (ekspose) sejak 11 November 2013.

Bahwa terdakwa Tubagus Chaeri Wardana (Wawan) dan kakaknya Ratu Atut Chosiyah diduga korupsi pengadaan alat kesehatan (Alkes) Provinsi Banten sebesar Rp 30,39 miliar, dan memberikan suap kepada Akil Mochtar terkait penanganan sengketa pilkada Lebak Banten, sebesar Rp 1 miliar.

Selain Wawan, penyidik juga menetapkan dua tersangka lain dengan pasal-pasal yang sama. Mereka adalah DP (Dadang Prihatna) dari pihak perusahaan PT MAP (Mikindo Adiguna Pratama), dan MJ (Mamak Jamaksari) yang menjabat Pejabat Pembuat Komitmen (PPK) proyek alkes tersebut.

Bahwa Terdakwa Mamak saat ini menjabat sebagai kepala Bidang Promosi Kesehatan dan Sumber Daya Manusia di Pemkot Tangsel. Johan mengungkapkan, dari proyek alkes Tangsel itu diduga terjadi penggelembungan harga. "Berapa mark up (penggelembungannya) saya belum diinformasikan penyidik. Nanti saya tanyakan lagi," paparnya. Johan menyatakan ada beberapa dokumen yang disita KPK. Dokumen itu tentu akan ditelaah apakah berkaitan dengan kasus yang ditangani atau tidak. Yang 
jelas, dokumen itu bisa membantu KPK untuk mendalami kasus ini." Rinciannya masih ada di penyidik.

\section{KESIMPULAN}

1. Peranan Perbankan Dalam Pencegahan Dan Pemberantasan

Tindak Pidana Pencucian Uang Adalah Sangat Penting Karena Paling Sedikit Ada 3 Tujuan Kriminalisasi Pencucian Uang. Pertama, Pencucian Uang Merupakan Masalah Yang Serius Bagi Dunia International, Maka Harus Dilakukan Kriminalisasi. Kedua, Aturan Anti Pencucian Uang Dipandang Sebagai Cara Yang Paling Efektif Untuk Mencari Pemimpin Organisasi Kejahatan Ekonomi (Leaders Of Organize Criminal Enterprise). Ketiga,Bbahwa Pelaku Pencucian Uang Lebih Mudah Di Tangkap Dari Pada Menangkap Pelaku Kejahatan Utamanya (Predicate Offence). Oleh Karenanya Salah Satu Tujuan Kriminalisasi Pencucian Uang Termasuk Untuk Melindungi Keuangan Internasional. Tujuan Seperti Ini Juga Nampak Dalam European Council / Council Directive 91/308, Tahun 1991 Yang Pada Dasarnya Untuk Mencegah Di Gunakannya Fasilitas Perbankan Dalam Praktik Pencucian Uang.

2. Peranan Perbankan Dalam Pencegahan Dan Pemberantasan Tindak Pidana Pencucian Uang Adalah Sangat Penting Karena Paling Sedikit Ada 3 Tujuan Kriminalisasi Pencucian Uang. Pertama, Pencucian Uang Merupakan Masalah Yang Serius Bagi Dunia International. Kedua, Aturan Anti Pencucian Uang Dipandang Sebagai Cara Yang Paling Efektif Untuk Mencari Pemimpin Organisasi Kejahatan Ekonomi (Leaders Of Organize Criminal Enterprise). Ketiga, Bahwa Pelaku Pencucian Uang Lebih 
Mudah Di Tangkap Dari Pada Menangkap Pelaku Kejahatan Utamanya (Predicate Offence).

\section{SARAN}

1. Dalam melakukan penegakan hukum materill dibidang Tindak Pidana Pencucian Uang dalam Transaksi Perbankan perlu adanya peran berbagai pihak. Seperti teori Lawrance M. Friedman tentang Three Element of Legal System bahwa perlu adanya peran Substansi, Subyek, Kultur hukum agar dapat ditegakkannya suatu hukum.

2. Berkenaan dengan pencegahan dan pemberantasan pencucian uang pada Bank maka dikeluarkan "Prinsip Mengenai Nasabah" (KYC) dimana Prinsip mengenai Nasabah ini dilaksanakan dengan cara mengenal dan mengetahui identitas nasabah, memantau transaksi dan memelihara profil nasabah, serta melaporkan adanya transaksi keuangan yang mencurigakan yang dilakukan oleh pihak yang menggunakan jasa bank.

\section{DAFTAR PUSTAKA}

\section{BUKU}

Adrian Sutedi. 2008. Tindak Pidana Pencucian Uang. Bandung: PT. CITRA ADITYA BAKTI

Adrian Sutedi. 2007. Hukum Perbankan Suatu Tinjauan Pencucian Uang, Merger, Likuidasi, dan Kepailitan. Jakarta: SINAR GRAFIKA

Ivan Yustiavandana, Arman Nefi, Aiwarman. 2010. Tindak Pidana Pencucian Uang di Pasar Modal. Bogor: Ghalia Indonesia.

Amin Widjaja Tunggal. 2014. Pencegahan Pencucian Uang (Money Laundering Prevention). Jakarta: HARVARINDO.

Arief Amrullah. 2004. Tindak Pidana Pencucian Uang Money Laundering. Malang: Bayumedia.

N.H.T. Siahaan. 2008. Money Laundering \& Kejahatan Perbankan. Jakarta: JALA 
Hermansyah. 2005. Hukum Perbankan Nasional Indonesia. Jakarta: KENCANA

Romli Atmasasmita. 2014. Hukum Kejahatan Bisnis. Jakarta: PRENADAMEDIA GROUP.

Zainal Abidin Farid. 2010. Hukum Pidana 1. Jakarta: Sinar Grafika

Moeljatno. 1983. AZAS-AZAS HUKUM PIDANA. Jakarta: BINA AKSARA

Andi Hamzah. 1996. HUKUM PIDANA EKONOMI. Jakarta: Erlangga

Sentosa Sembiring. 2012. HUKUM PERBANKAN EDISI REVISI. Bandung: Mandar Maju

\section{B. Undang-Undang}

Undang-Undang Nomor 8 Tahun 2010 tentang Tindak Pidana Pencucian Uang

Undang-Undang Nomor 3 Tahun 2004 tentang Bank Indoneisa

Kitab Undang-Undang Hukum Pidana

Kitab Undang-Undang Hukum Acara Pidana

\section{Artikel dan Website}

Muhammad Nurul Huda. Makalah: Azas Pembuktian Terbalik Tindak Pidana Pencucian Uang dalam Globalisasi Hukum.

Yunus Husein. Makalah: UPAYA MEMBERANTAS PENCUCIAN UANG (MONEY LAUNDERING)

Yunus Husein. Makalah: KEBIJAKSANAA BANK INDONESIA TENTANG PENCUCIAN UANG (MONEY LAUNDERING)

Yunus Husein. Makalah: PENCEGAHAN DAN PEMBERANTASAN TINDAK PIDANA PENCUCIAN UANG DI INDONESIA.

Yunus Husein. Makalah: IMPLEMENTASI UU NO. 15 TAHUN 2002 DAN KAITANNYA DENGAN PERATURAN PERUNDANGUNDANGAN LAINNYA.

Yunus Husein. Makalah: KEGIATAN PEMUTIHAN UANG (MONEY LAUNDERING).

http://www.bi.go.id/id/tentang-bi/fungsi-

bi/status/Contents/Default.aspx

www.bi.go.id/id/tentang-bi/fungsi-bi/misi-visi/Contents/Default.asp 
http: //news.metrotvnews.com/hukum/yNLEYBPb-kpk-periksa-wawansebagai-tersangka-kasus-pencucian-uang

https: / /nasional.tempo.co/read/news/2016/03/01/063749440/telusuripencucian-uang-wawan-kpk-periksa-tiga-saksi-lagi

https: / / nasional.tempo.co/read/news/2016/01/04/063732830/kpkterus-dalami-kasus-pencucian-uang-adik-atut 
